\title{
HYPOXIC REGULATION OF MYBL1, MEST, TCF3, TCF8, GTF2B, GTF2F2 AND SNAI2 GENES EXPRESSION IN U87 GLIOMA CELLS UPON IRE1 INHIBITION
}

\author{
O. H. MINCHENKO', D. O. TSYMBAL ${ }^{1}$, D. O. MINCHENKO ${ }^{1,2}$, O. O. KUBAYCHUK ${ }^{3}$ \\ ${ }^{1}$ Palladin Institute of Biochemistry, National Academy of Sciences of Ukraine, Kyiv; \\ e-mail: ominchenko@yahoo.com; \\ ${ }^{2}$ Bohomolets National Medical University, Kyiv, Ukraine; \\ ${ }^{3}$ National University of Food Technologies, Kyiv, Ukraine
}

We investigated the impact of IRE1/ERN1 (inositol requiring enzyme 1/endoplasmic reticulum to nucleus signaling 1) knockdown on hypoxic regulation of the expression of a subset of proliferation and migration-related genes in U87 glioma cells. It was shown that hypoxia leads to up-regulation of the expression of MEST and SNAI2, to down-regulation - of MYBL1, TCF8 and GTF2F2 genes at the mRNA level in control glioma cells. At the same time hypoxia did not affect the expression of TCF3 and GTF2B transcription factor genes. In turn, inhibition of IREI modified the effect of hypoxia on the expression of all studied genes, except MYBL1 and GTF2B. For instance, IRE1 knockdown decreased sensitivity to hypoxia of the expression of MEST, TCF8 and SNAI2 genes and increased sensitivity to hypoxia of GTF2F2 expression. At the same time, IRE1 inhibition introduced sensitivity to hypoxia of the expression of TCF3 gene in glioma cells. The present study demonstrated that the inhibition of IREI in glioma cells affected the hypoxic regulation of the expression of studied genes in various directions, though hypoxic conditions did not abolish the effect of IREI inhibition on the expression of respective genes. To the contrary, in case of SNAI2, GTF2F2 and MEST hypoxic conditions magnified the effect of IRE1 inhibition on the expression of respective genes in glioma cells.

Key word s: mRNA expression, MYBL1, TCF3, TCF8, SNAI2, GTF2B, GTF2F2, MEST, IRE1 inhibition, hypoxia, glioma cells.

$\mathrm{T}$ ranscription factors MYBL1 (Myb-like protein 1), TCF3 (transcription factor 3), TCF8 (transcription factor 8), SNAI2 (Snail homolog 2), GTF2B (general transcription factor IIB), GTF2F2 (general transcription factor IIF, polypeptide 2), as well as potential tumor suppressor MEST (mesoderm specific transcript) are implicated in control of various cellular processes, in particular, proliferation and migration [1-10]. Role of MYBL1 transcription factor in tumor development is still under investigation. However, it is known, that partial duplication of MYBL1 gene together with truncation of its C-terminal regulatory domain is frequently observed in pediatric gliomas [7]. Transcription factor TCF3 functions both as transcriptional activator and repressor depending on its interactions with partner proteins. For instance, CBP/p300 participates in transcriptional activation, whereas ETO family factors contribute to repression of transcription [1, 2]. Role of TCF3 in development of malignancies is ambiguous, but decreased expression of this factor correlates with negative prognosis in patients with colon cancer [3]. On the other hand, over-expression of TCF3 is observed in breast, stomach, kidney tumors and hepatocellular carcinoma [4].

Among others, transcription factors SNAI2, TCF8 and TCF3 are identified as key regulators of invasive phenotype development in different types of tumors. These factors are pleiotropically expressed and their effects are partially redundant. For instance, SNAI2, TCF8 and TCF3 are negative regulators of E-cadherin expression, as they recognize regulatory E-box elements in promoter region of this gene [4-6]. Experimental over-expression of transcription factors SNAIL, SNAI2, ZEB1/2 of TWIST1/2 in epithelial cells leads, as a rule, to initiation of epithelial-mesenchymal transition: loss of adherent junctions, conversion of cells from polygonal into fusiform, expression of enzymes, which cleave the components of extracellular matrix, increased mobility and resistance to apoptosis [11, 12]. 
PEG1/MEST (paternally expressed gene 1/ mesoderm specific transcript) is a gene, localized in chromosome 7q32.2, characterized by genome imprinting, meaning that only its paternal allele is expressed, whereas the expression of maternal allele is blocked due to hypermethylation. This gene encodes an enzyme, which belongs to the family of alpha/ beta hydrolases [13]. It was demonstrated, that loss of methylation of one of the PEG1/MEST alleles increases the risk of cervical cancer development [14]. Aberrant PEG1/MEST imprinting was detected in invasive breast tumors and uterine leiomyomas [15-17]. In case of hepatocellular carcinoma, in contrast, the down-regulation of PEG1/MEST expression is observed due to hypermethylation of its promoter [8]. It is interesting to note, that one of the intrones of the PEG1/MEST gene codes a tumor suppressor microRNA miR-335, which inhibits the metastatic abilities of tumor cells [8]. Therefore, the hypermethylation of the promoter of this gene consecutively decreases the expression of MEST and miR-335 [8]. It needs to be clarified to which extend the tumor suppressor effect of MEST is determined by the expression of its protein product or an intron-localized miR-335.

General transcription factor 2B is involved in RNA polymerase II recruitment and initiation of transcription in eukaryotes [18]. Recently, it was shown, that the expression of this transcription factor is increased in hepatocellular carcinoma in comparison to normal tissues on both mRNA and protein levels. Moreover, it was found that elevated levels of GTF2B in hepatocellular carcinoma cells are associated with transition from G1 to S phase, and cell growth assay shows that overexpression of TFIIB may promote cell proliferation [9].

GTF2F2 is an ATP-dependent DNA-helicase, which exists as a heterodimer with another general transcription factor GTF2F1. The complex is active in both initiation and elongation stages of transcription controlling the activity of RNA polymerase II [19]. The possible significance of GTF2F2 for cancer development is still to be investigated, however, it is known, that this transcription factor is downregulated in cervical cancer specimens in comparison to normal tissues [20, 21]. Recently, GTF2F2 was identified as a new target gene of a tumor suppressor transcription factor delta-lactoferrin in MDAMB-231 breast cancer cells [10].

Presence of hypoxic regions in tumors increases their resistance to chemo- and radiotherapy, in particular, due to ineffective diffusion of drugs and slower cell division, which usually accompanies hypoxia. Moreover, cycles of hypoxia-reoxygenation increase the migration potential of tumor cells [22, 23]. For many types of tumors there is a correlation between HIF (hypoxia inducible factor) activation and decreased expression of E-cadherin, a key tumor suppressor, which inhibits epithelial-mesenchymal transition. In general, hypoxia modifies the physiology of a neoplasm towards more aggressive phenotype [24].

Activation of an endoplasmic reticulum stress signaling pathway plays an important role in adaptation of tumor cells to the decreased levels of oxygen. In particular, a protein kinase PERK is activated under hypoxic conditions, which leads to the phosphorylation of translation initiation factor eIF $2 \alpha$, and therefore - to overall decrease in protein synthesis. Moreover, PERK-mediated phosphorylation of eIF $2 \alpha$ activates the translation of an ATF4 transcription factor, which facilitates cell survival under stressful conditions [25]. It is also known, that activation of PERK-dependent branch of endoplasmic reticulum stress facilitates the adaptation of cells to prolonged hypoxia and development of resistance to apoptosis [26]. Activation of IRE1 (inositol requiring enzyme-1)-dependent branch of endoplasmic reticulum stress pathway is no less important for the adaptation to hypoxic conditions. For instance, IRE1 activation leads to the expression of an active XBP1 (X-box protein 1) transcription factor, which promotes survival of tumor cells [27]. It was demonstrated, that VEGF expression and angiogenesis in tumors under hypoxic conditions is also IRE1-dependent [28].

Gliomas, as many other types of solid tumors, are characterized by the presence of hypoxic and necrotic regions. Through activation of various signaling pathways, in particular - endoplasmic reticulum stress response, gliomas utilize hypoxic conditions to stimulate the neovascularization, tumor growth and invasion [29].

In this study we investigated the impact of hypoxia on the expression of a subset of proliferation and migration-related genes in U87 glioma cells in relation to functional activity of a key endoplasmic reticulum stress effector IRE1.

\section{Materials and Methods}

Cell lines and culture conditions. The glioma cell line U87 (HTB-14) was obtained from ATCC (USA) and grown in high glucose (4.5 g/l) Dulbecco's modified Eagle's minimum essential medium 
(DMEM; Gibco, Invitrogen, USA) supplemented with glutamine (2 mM), 10\% fetal bovine serum (Equitech-Bio, Inc., USA), penicillin (100 units/ml; Gibco, USA) and streptomycin (0.1 mg/ml; Gibco) at $37^{\circ} \mathrm{C}$ in a $5 \% \mathrm{CO}_{2}$ incubator.

In this study we used sublines of U87 glioma cells, which were described previously [30-32]. One subline was obtained by selection of stable transfected clones with overexpression of vector pcDNA3.1, which was used for creation of dnERN1. Second subline was obtained by selection of stable transfected clone with overexpression of IRE1 dominant-negative construct (dnERN1) and has suppressed protein kinase and endoribonuclease activities of this signaling enzyme (clone 1C5) [31]. The expression level of studied genes in these two sublines of glioma cells was compared with corresponding cells, transfected by vector or by dnERN1 construct. The efficiency of IRE1 suppression in this glioma cell subline was estimated previously [33, 34]. Both sublines of glioma cells used in this study were grown with the addition of geneticin (G418) while these cells are carrying empty vector pcDNA3.1 or dnERN1 construct.

For hypoxia culture plates were exposed in special chamber with $3 \%$ oxygen, $92 \%$ nitrogen, and 5\% carbon dioxide levels for $16 \mathrm{~h}$.

RNA isolation. Total RNA was extracted from glioma cells using Trizol reagent according to manufacturer protocols (Invitrogen, USA) as described previously [34]. The RNA pellets were washed with $75 \%$ ethanol and dissolved in nuclease-free water. For additional purification, RNA samples were re-precipitated with 95\% ethanol and re-dissolved again in nuclease-free water. RNA concentration and spectral characteristics were measured using NanoDrop Spectrophotometer ND1000 (PEQLAB, Biotechnologie GmbH).

Reverse transcription and quantitative PCR analysis. QuaniTect Reverse Transcription Kit (QIAGEN, Germany) was used for cDNA synthesis according to manufacturer protocol. The expression levels of MYBL1, TCF3, TCF8, SNAI2, MEST, GTF2B and GTF2F2 mRNAs as well as ACTB mRNA were measured in U87 glioma cells and their dnERN1 subline by real-time quantitative polymerase chain reaction using Mx 3000P QPCR (Stratagene, USA) or "RotorGene RG-3000" qPCR (Corbett Research, Germany) and Absolute qPCR SYBRGreen Mix (Thermo Fisher Scientific, ABgene House, UK). Polymerase chain reaction was performed in triplicate using specific primers, which were received from Sigma-Aldrich (St. Louis, MO, USA).

For amplification of MYBL1 cDNA we used forward ( $5^{\prime}$-TTGAAGGATGCGAAGAGGT- $\left.3^{\prime}\right)$ and reverse (5'-CATCGATGCTGGCACTGAAA-3') primers. The nucleotide sequences of these primers correspond to sequences 401-420 and 637-618 of human MYBL1 cDNA (GenBank accession number NM_001080416). The size of amplified fragment is 237 bp.

The amplification of TCF3 cDNA for real time RCR analysis was performed using two oligonucleotides primers: forward - 5'-ACAAGGAGCTCAGTFACCTC- $3^{\prime}$ and reverse $-5^{\prime}-\mathrm{CT}$ GTFCGACTCAGTFAAGTF-3'. The nucleotide sequences of these primers correspond to sequences 107-126 and 326-307 of human TCF3 cDNA (GenBank accession number NM_003200). The size of amplified fragment is $220 \mathrm{bp}$.

The amplification of TCF8 cDNA for real time RCR analysis was performed using two oligonucleotides primers: forward - 5'-CAGGGAGGAGCAGTFAAAGA- $3^{\prime}$ and reverse $-5^{\prime}$-CTCTTCAGGTFCCTCAGGAA- $3^{\prime}$. The nucleotide sequences of these primers correspond to sequences 209-228 and 438419 of human TCF8 cDNA (GenBank accession number NM_030751). The size of amplified fragment is $230 \mathrm{bp}$.

For amplification of SNAI2 cDNA we used forward (5'-CCTGGTTGCTTCAAGGACAC- $3^{\prime}$ and reverse (5'-AGCAGCCAGATTCCTCATGT-3') primers. The nucleotide sequences of these primers correspond to sequences 765-784 and 968-949 of human SNAI2 cDNA (GenBank accession number NM_003068). The size of amplified fragment is 204 bp.

For amplification of MEST cDNA we used forward (5'-TTGGCTTCAGTGACAAACCG-3' and reverse (5'-TGACAGCACACCTCCATCTT-3') primers. The nucleotide sequences of these primers correspond to sequences 576-595 and 859-840 of human MEST cDNA (GenBank accession number NM_002402). The size of amplified fragment is $284 \overline{\mathrm{b}} \mathrm{p}$.

The amplification of GTF2F2 cDNA was performed using two oligonucleotide primers: forward - 5'-GGAGTGTGGCTAGTCAAGGT-3' and reverse - 5'-GCACTGACTGAAGCTGGTTT-3'. The nucleotide sequences of these primers correspond to sequences 209-228 and 390-371 of human GTF2F2 cDNA (GenBank accession number 
NM_004128). The size of amplified fragment is 182 bp.

For amplification of GTF2B cDNA we used forward ( $5^{\prime}-$ TCTGTTGTGTCTTGTTGCGG- $3^{\prime}$ and reverse (5'-GTTCGCCATTCAGATCCCAC-3') primers. The nucleotide sequences of these primers correspond to sequences $80-99$ and 280-261 of human GTF2B cDNA (GenBank accession number NM_001514). The size of amplified fragment is 201 bp.

The amplification of $\beta$-actin (ACTB) cDNA was performed using forward - 5'-GGACTTCGAGCAAGAGATGG $-3^{\prime}$ and reverse - 5'-AGCACTGTGTTGGCGTACAG $-3^{\prime}$ primers. These primer nucleotide sequences correspond to 747-766 and 980-961 of human ACTB cDNA (GenBank accession number NM_001101). The size of amplified fragment is $234 \mathrm{bp}$. The expression of $\beta$-actin mRNA was used as control of analyzed RNA quantity.

Quantitative PCR analysis was performed using a special computer program "Differential expression calculator". The values of MYBL1, TCF3, TCF8, SNAI2, MEST, GTF2B, GTF2F2 and ACTB gene expressions were normalized to the expression of $\beta$-actin mRNA and represented as percent of control (100\%). All values are expressed as mean \pm SEM from triplicate measurements performed in 4 independent experiments.

Statistical analysis. The statistical hypotheses were tested using the STATISTICA v.7 for every gene: MEST, MYBL1, TCF3, TCF8, GTF2B, SNAI2, and GTF2F2. The samples were normally distributed. It follows from the sampling process and testing with Normal-Probability Plot. Effect of hypoxia in dnERN1 cells was evaluated with Wald-Wolfowitz and Mann-Whitney tests as a nonparametric alternative to the $t$-test for independent samples. All three tests delivered similar outcomes.

\section{Results and Discussion}

We investigated the effect of hypoxic conditions on the expression of a subset of genes encoding proliferation and migration related transcription factors as well as a potential tumor suppressor MEST in U87 glioma cells in relation to functional activity of IRE1 signaling enzyme. We determined, that in control U87 glioma cells, transfected with an empty pcDNA3.1 vector, hypoxia led to a moderate down-regulation (-32\%) of the expression of MYBL1 mRNA (Fig. 1). In cells with IRE1/ERN1 knockdown (dnERN1) we also observed a decreased expression of this transcription factor (-23\%) under hypoxic conditions, in comparison to cells cultivated with normal amounts of oxygen. Therefore, inhibition of IRE1 signaling enzyme in glioma cells did not significantly affect the hypoxic regulation of MYBL1 expression, though in glioma cells with IRE1 knockdown we observed a 6-fold increase in MYBL1 mRNA levels in comparison to cells, expressing native IRE1 (Fig. 1).

As shown in Fig. 2, hypoxia did not affect the expression levels of TCF3 mRNA in control U87 glioma cells. However, inhibition of IRE1 kinase and RNase introduced sensitivity to hypoxia of this gene expression. Namely, mRNA levels of TCF3 transcription factor in dnERN1 glioma cells were upregulated (+32\%) under hypoxic conditions (Fig. 2). Therefore, in case of TCF3, treatment with hypoxia augmented the effect of IRE1 inhibition on the expression of this gene.

We demonstrate, that hypoxia led to a marked (-58\%) down-regulation of TCF8 expression in U87

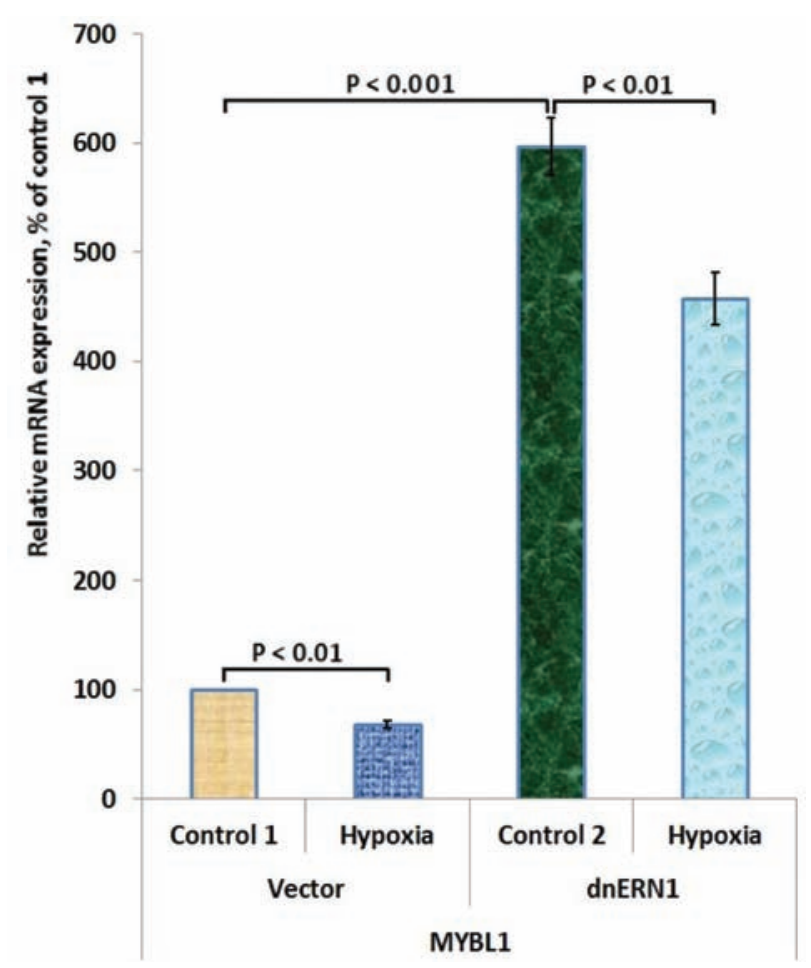

Fig. 1. Effect of hypoxia (3\% oxygen -16 h) on the expression level of transcription factor MYBL1 in control U87 glioma cells (Vector) and cells with inhibition of IRE1/ERN1 enzymatic activities (dnERN1) measured by qPCR. The values of MYBL1 mRNA expression were normalized to $\beta$-actin $m R N A$ level and presented as percent of control (100\%); $n=4$ 


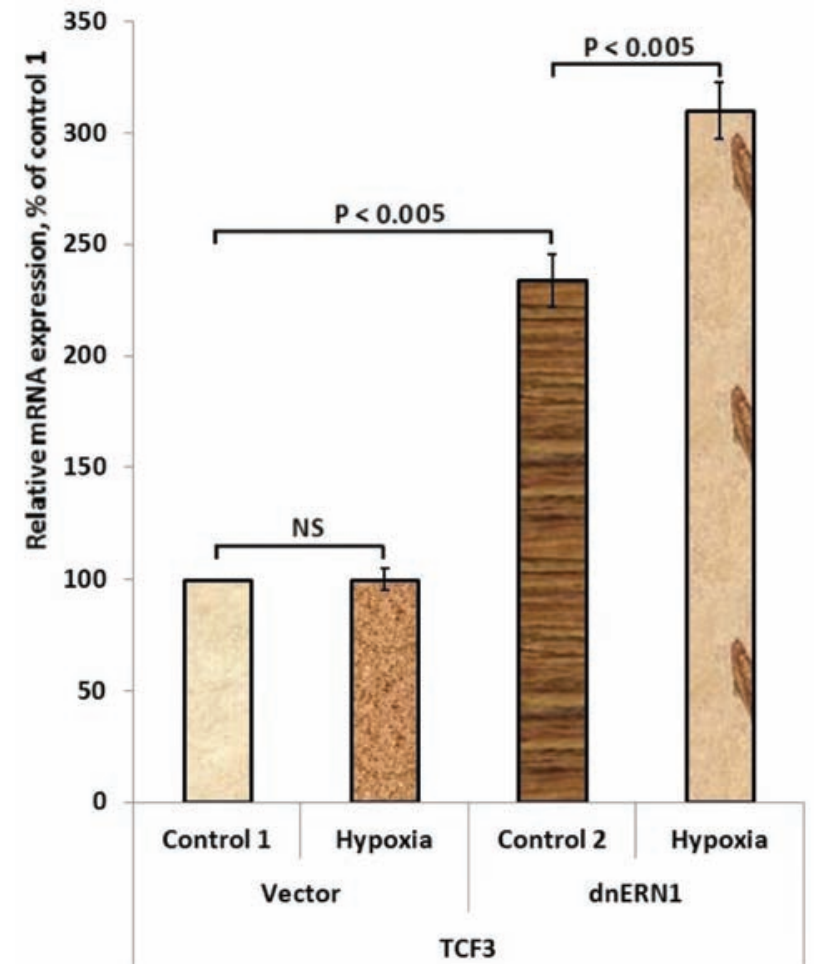

Fig. 2. Effect of hypoxia (3\% oxygen -16 h) on the expression level of transcription factor TCF3 in control U87 glioma cells (Vector) and cells with inhibition of IRE1/ERN1 enzymatic activities (dnERN1) measured by qPCR. The values of TCF3 mRNA expression were normalized to $\beta$-actin $m R N A$ level and presented as percent of control (100\%); $n=4$

glioma cells (Fig. 3). In cells, expressing dominantnegative IRE1/ERN1, we observed decreased expression of this transcription factor mRNA (-28\%) under hypoxic conditions in comparison to dnERN1 cells, which were cultivated with normal amounts of oxygen (Fig. 3). Thus, we can conclude, that IRE1 inhibition in U87 glioma cells decreased the sensitivity of TCF8 expression to hypoxia.

We observed, that low levels of oxygen led to a marked (+74\%) up-regulation of SNAI2 mRNA expression in U87 glioma cells, transfected with empty vector (Fig 4). At the same time, in dnERN1 cells hypoxic conditions led only to a $16 \%$ increase in expression of this transcription factor mRNA (Fig.4). Therefore, as in case of TCF8 inhibition of IRE1 signaling enzyme in glioma cells led to decreased sensitivity of SNAI2 expression to hypoxia. At the same time, in glioma cells with IRE1 knockdown we observed a prominent up-regulation of SNAI2 expression in comparison to control cells with na-

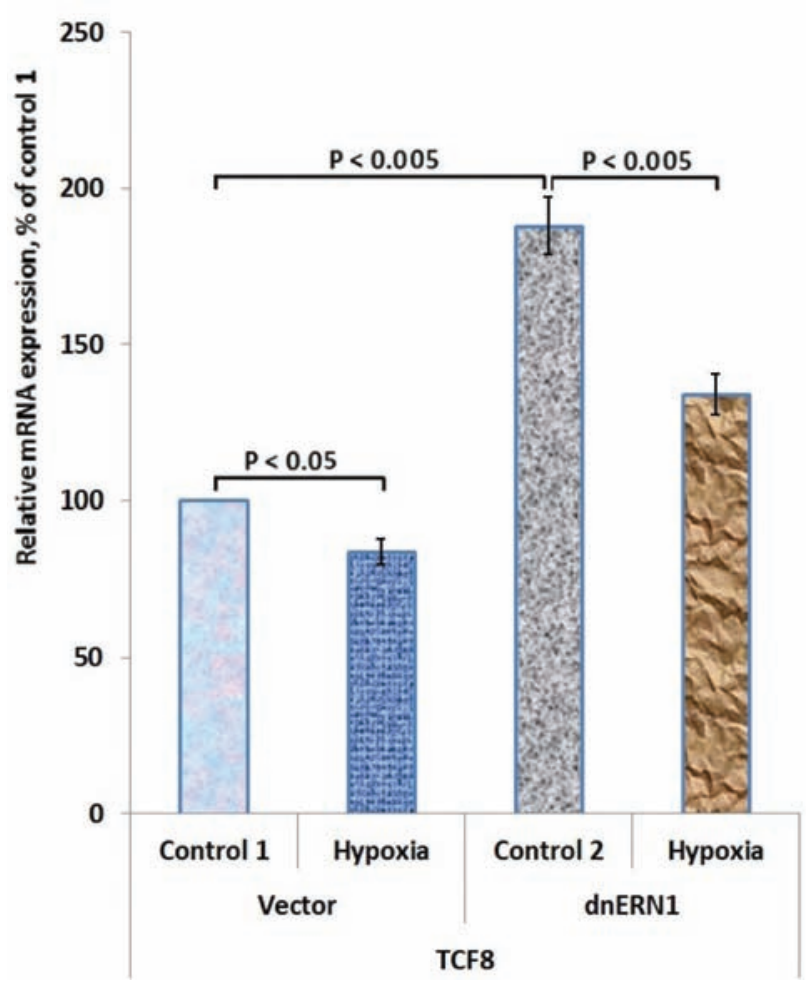

Fig. 3. Effect of hypoxia (3\% oxygen -16 h) on the expression level of transcription factor TCF8 in control U87 glioma cells (Vector) and cells with inhibition of IRE1/ERN1 enzymatic activities (dnERN1) measured by qPCR. The values of TCF8 mRNA expression were normalized to $\beta$-actin $m R N A$ level and presented as percent of control (100\%); $n=4$

tive IRE1 (Fig. 4). Moreover, hypoxic treatment of dnERN1 cells augmented the effect of IRE1 inhibition on the expression of SNAI2.

In case of potential tumor suppressor MEST, its expression was up-regulated almost 2-fold in U87 glioma cells subjected to hypoxia (Fig. 5). Inhibition of IRE1 signaling enzyme in glioma cells led to more than 8-fold increase in expression of its mRNA in comparison to cells with native IRE1 (Fig. 5). Furthermore, hypoxic treatment of dnERN1 cells resulted in 28\% increase in MEST expression (Fig. 5). Thus, we can conclude, that IRE1 knockdown decreased the sensitivity of this gene's expression to hypoxia in U87 glioma cells.

Hypoxia did not affect significantly the expression of general transcription factor 2B in U87 glioma cells with native IRE1 (Fig. 6). Upon inhibition of IRE1 we observed a $60 \%$ decrease in expression of this transcription factor, and hypoxia slightly increases the expression of GTF2B gene in glioma 


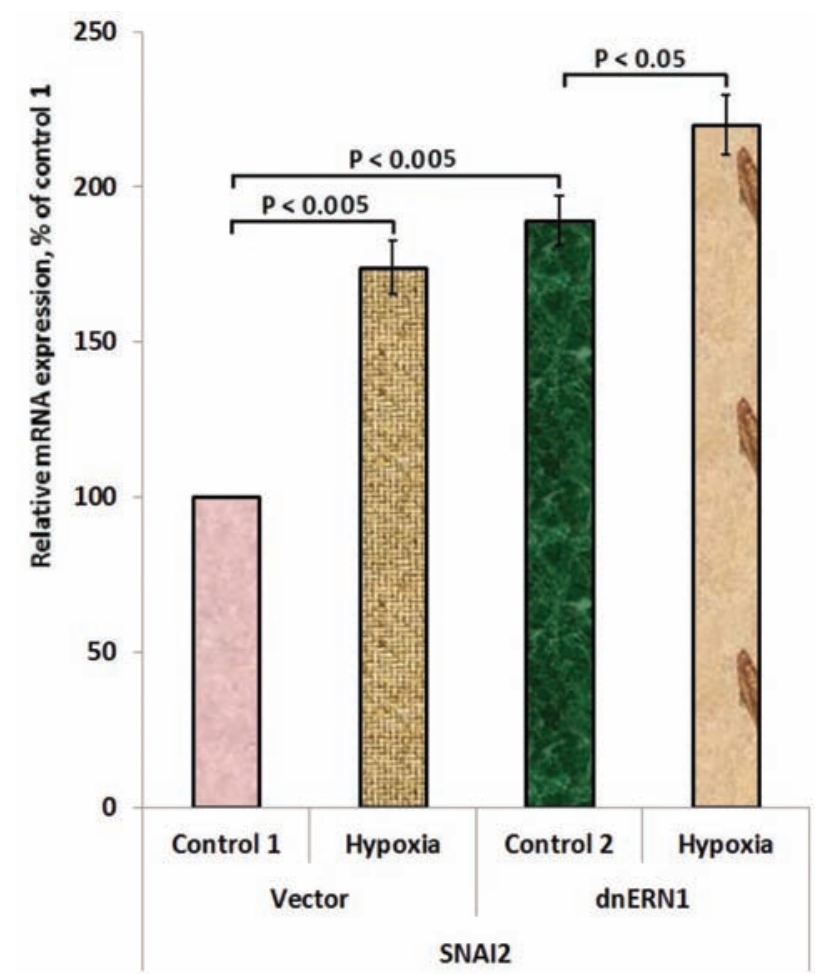

Fig. 4. Effect of hypoxia (3\% oxygen - 16 h) on the expression level of transcription factor SNAI2 in control U87 glioma cells (Vector) and cells with inhibition of IRE1/ERN1 enzymatic activities (dnERN1) measured by qPCR. The values of SNAI2 mRNA expression were normalized to $\beta$-actin mRNA level and presented as percent of control (100\%); $n=4$

cells with IRE1 knockdown (Fig. 6). In contrast, treatment with hypoxia led to a $46 \%$ decrease in GTF2F2 mRNA expression in glioma cells (Fig. 7). Moreover, in dnERN1 glioma cells, subjected to hypoxia, the expression of GTF2F2 was further downregulated (-64\%) in comparison to control dnERN1 cells, cultivated with normal amounts of oxygen (Fig. 6). Thus, the hypoxic regulation of GTF2F2 expression in glioma cells is IRE1-dependent and inhibition of IRE1 increases the effect of hypoxia on the expression of this transcription factor.

In this work we studied the expression of a number of proliferation-related transcription factor genes, as well as of a potential tumor suppressor MEST in U87 glioma cells with an unaltered IRE1 signaling enzyme and in cells with IRE1 knockdown upon hypoxic conditions. The aim of the study was to evaluate the effect of IRE1 inhibition on the hypoxic regulation of the expression of selected genes, as both hypoxia and ER stress are key factors, which control cellular proliferation and tumor growth in

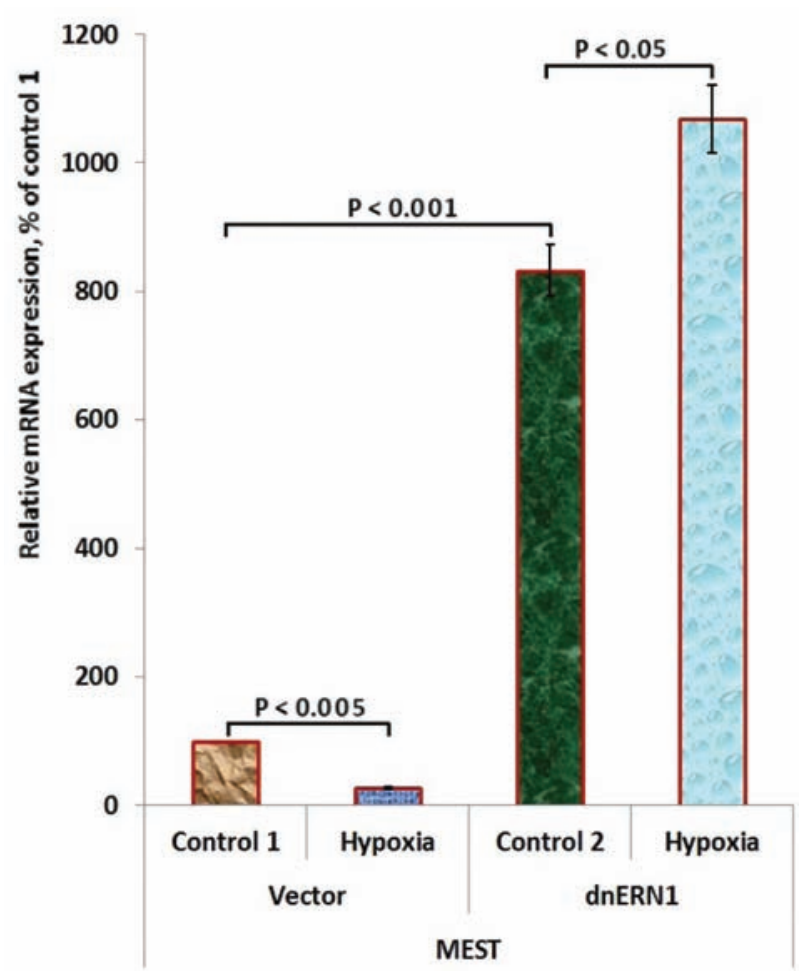

Fig. 5. Effect of hypoxia (3\% oxygen -16 h) on the expression level of gene MEST in control U87 glioma cells (Vector) and cells with inhibition of IRE1/ ERN1 enzymatic activities (dnERN1) measured by qPCR. The values of MEST mRNA expression were normalized to $\beta$-actin $m R N A$ level and presented as percent of control (100\%); $n=4$

gliomas and many other types of cancers [35-39]. The growing tumor utilizes the endoplasmic reticulum stress and hypoxia responses to promote the formation of new blood vessels, cellular proliferation, as well as to acquire resistance to apoptosis [28, 33, 35]. Numerous data [35, 36, 38-40] are available that cellular response to hypoxia is associated with malignant progression through the endoplasmic reticulum stress signaling pathway, however, the precise mechanism of such interconnection remains largely unknown.

In this study we have demonstrated that the expression of most studied genes, except TCF3 and GTF2B in control glioma cells is affected by hypoxia as compared to normoxic condition. For instance, the expression levels of MEST and SNAI2 genes were increased upon hypoxia in U87 glioma cells with native IRE1, whereas the relative mRNA levels of transcription factors MYBL1, TCF8 and GTF2F2 were decreased under hypoxic conditions in comparison to control. Inhibition of IRE1 signaling enzyme in 


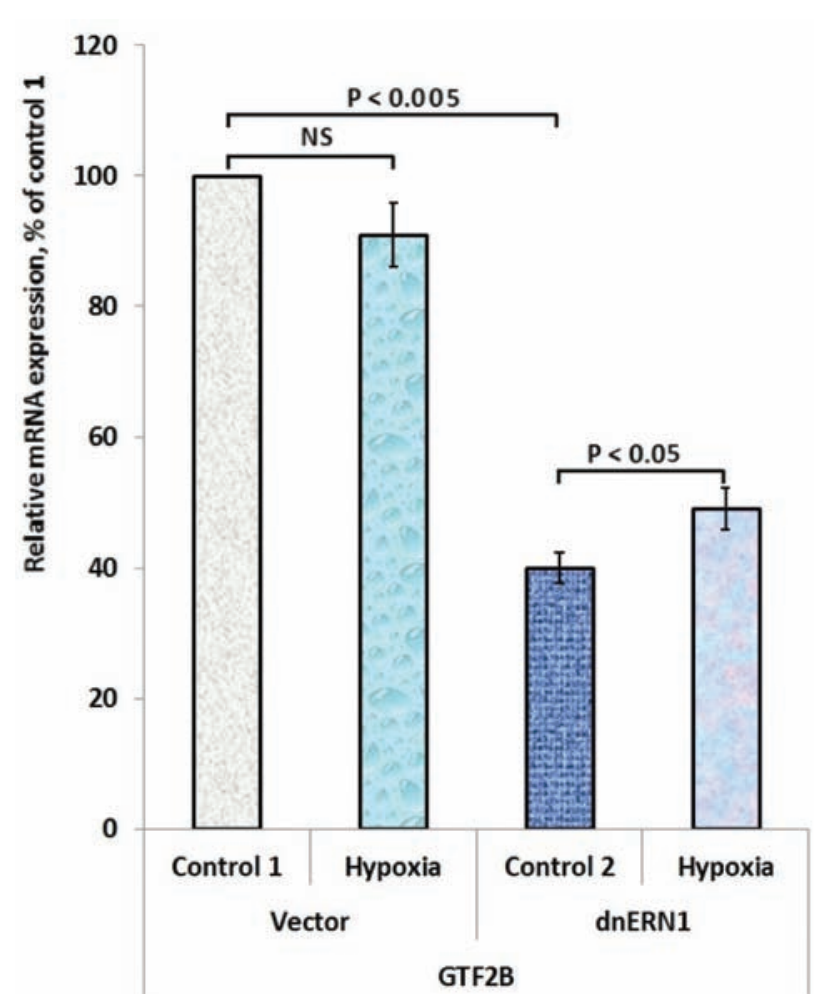

Fig. 6. Effect of hypoxia (3\% oxygen - 16 h) on the expression levels of transcription factors GTF2B in control U87 glioma cells (Vector) and cells with inhibition of IRE1/ERN1 enzymatic activities (dnERN1) measured by qPCR. The values of GTF2B mRNA expression were normalized to $\beta$-actin $m R N A$ level and presented as percent of control (100\%); $n=4$

glioma cells did not significantly affect the hypoxic regulation of MYBL1 expression.

In case of TCF3 and GTF2B transcription factors, inhibition of IRE1 signaling enzyme introduces the hypoxic regulation of the expression of these genes. In contrast, IRE1 knockdown in U87 glioma cells decreased the sensitivity of TCF8, SNAI2 and MEST expression to hypoxia. Only in case of GTF2F2 transcription factor IRE1 inhibition resulted in increased sensitivity of this gene's expression to hypoxia in glioma cells.

It is interesting to note, that in all cases treatment with hypoxia did not abolish the effect of IRE1 knockdown on the expression of studied genes. Moreover, in case of pro-migratory transcription factors TCF3 and SNAI2, hypoxic treatment of dnERN1 cells augmented the effect of IRE1 inhibition on the expression of these genes. It is known,

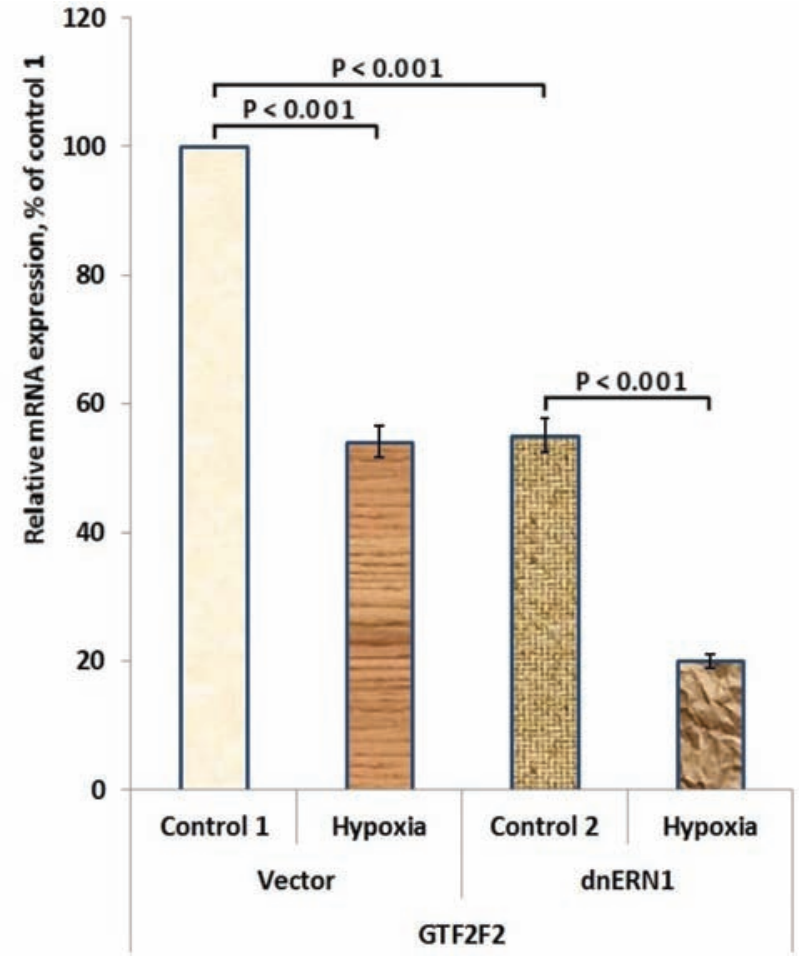

Fig. 7. Effect of hypoxia (3\% oxygen - 16 h) on the expression levels of transcription factors GTF2B and GTF2F2 in control U87 glioma cells (Vector) and cells with inhibition of IRE1/ERN1 enzymatic activities (dnERN1) measured by qPCR. The values of GTF2B and GTF2F2 mRNA expression were normalized to $\beta$-actin $m R N A$ level and presented as percent of control (100\%); $n=4$

that suppression of IRE1 enzymatic activities in gliomas leads to the inhibition of tumor neovascularization together with the development of a more invasive phenotype [33, 34]. It is reasonable to suggest, that combined impact of hypoxia and IRE1 inhibition on the expression of key pro-migratory transcription factors may contribute to the increased migration potential of IRE1 knockdown glioma cells.

The present study demonstrates that hypoxia, which is a major factor influencing glioma growth, affects almost all studied genes expression and that inhibition of IRE1 modifies the hypoxic regulation of these gene expressions in gene specific manner. However, little is known about the detailed molecular mechanisms of IRE1-mediated hypoxic regulation of these genes. 


\section{ГІПОКСИЧНА РЕГУЛЯЦІЯ ЕКСПРЕСIÏ ГЕНIВ MYBL1, MEST, TCF3, TCF8, GTF2B, GTF2F2 TA SNAI2 У КЛІТИНАХ ГЛІОМИ U87 ЗА ІНГІБУВАННЯ IRE1}

\author{
О. Г. Мінченко1, Д. О. Цимбал \\ Д. О. Мінченко ${ }^{1,2}$ О. О. Кубайчук ${ }^{3}$
}
${ }^{1}$ Інститут біохімії ім. О. В. Палладіна НАН України, Київ; e-mail: ominchenko@yahoo.com; ${ }^{2}$ Національний медичний університет ім. О. О. Богомольця, Київ, Україна; ${ }^{3}$ Національний університет харчових технологій, Київ, Україна

Досліджено вплив пригнічення IRE1/ERN1 (inositol requiring enzyme 1 / endoplasmic reticulum to nucleus signaling 1) на гіпоксичну регуляцію експресії низки генів, причетних до контролю проліферації та міграції, в клітинах гліоми лінії U87. Показано, що гіпоксія призводить до зростання експресії генів MEST та SNAI2 та до зниження експресії генів MYBL1, TCF8 і GTF2F2 на рівні мРНК у контрольних клітинах гліоми. $\mathrm{y}$ той самий час гіпоксія не чинить впливу на експресію генів транскрипційних факторів TCF3 та GTF2B. У свою чергу інгібування IRE1 модифікує вплив гіпоксії на експресію всіх досліджуваних генів, за винятком MYBL1 та GTF2B. Зокрема, виключення IRE1 знижує чутливість експресії генів MEST, TCF8 та SNAI2 до гіпоксії i, навпаки, підвищує чутливість експресії гена GTF2F2 до дії цього чинника. Водночас інгібування IRE1 ініціює гіпоксичну регуляцію експресії гена TCF3 в клітинах гліоми. Показано, що пригнічення IRE1 y клітинах гліоми має різноспрямований вплив на гіпоксичну регуляцію експресії досліджуваних генів, однак, гіпоксія в жодному разі не усуває впливу пригнічення IRE1 на їх експресію. Навпаки, у разі з SNAI2, GTF2F2 та MEST умови гіпоксії посилюють ефект пригнічення IRE1 на їх експресію в клітинах гліоми.

К лючов і слова: експресія мРНК, MYBL1, TCF3, TCF8, SNAI2, GTF2B, GTF2F2, MEST, пригнічення IRE1, гіпоксія, клітини гліоми.

\section{ГИПОКСИЧЕСКАЯ РЕГУЛЯЦИЯ ЭКСПРЕССИИ ГЕНОВ MYВL1, MEST, TCF3, TCF8, GTF2B, GTF2F2 И SNAI2 В КЛЕТКАХ ГЛИОМЫ U87 ПРИ ИНГИБИРОВАНИИ IRE1}

\author{
О. Г. Минченко1, Д. О. Цымбал 1 , \\ Д. О. Минченко ${ }^{1,2}$, О. О. Кубайчук ${ }^{3}$
}
${ }^{1}$ Институт биохимии им. А. В. Палладина НАН Украины, Киев; e-mail: ominchenko@yahoo.com;
${ }^{2}$ Национальный медицинский университет им. А. А. Богомольца, Киев, Украина; ${ }^{3}$ Национальный университет пищевых технологий, Киев, Украина

Исследовано влияние угнетения IRE1/ ERN1 (inositol requiring enzyme 1/ endoplasmic reticulum to nucleus signaling 1) на гипоксическую регуляцию экспрессии ряда генов, причастных к контролю пролиферации и миграции, в клетках глиомы линии U87. Показано, что гипоксия ведет к увеличению уровня экспрессии генов $M E S T$ и SNAI2, и к снижению уровней экспрессии MYBL1, TCF8 и GTF2F2 на уровне мРНК в контрольных клетках глиомы. В то же время, гипоксия не влияет на экспрессию транскрипционных факторов TCF3 и GTF2B. В свою очередь ингибирование IRE1 модифицирует влияние гипоксии на экспрессию всех исследуемых генов, кроме MYBL1 и GTF2B. В частности, выключение IRE1 снижает чувствительность экспрессии генов MEST, TCF8 и SNAI2 к гипоксии и, наоборот, повышает чувствительность экспрессии гена GTF2F2 к влиянию данного фактора. В то же время, ингибирование IRE1 инициирует гипоксическую регуляцию экспрессии гена TCF3 в клетках глиомы. Показано, что угнетение IRE1 в клетках глиомы имеет разнонаправленное влияние на гипоксическую регуляцию экспрессии исследуемых генов, однако, ни в одном из случаев гипоксия не нивелирует эффект угнетения IRE1 на их экспрессию. Наоборот, в случае SNAI2, GTF2F2 и MEST условия гипоксии усиливают эффект угнетения IRE1 на их экспрессию в клетках глиомы.

Ключевы е слова: экспрессия мРНК, MYBL1, TCF3, TCF8, SNAI2, GTF2B, GTF2F2, MEST, угнетение IRE1, гипоксия, клетки глиомы. 


\section{References}

1. Denis CM, Langelaan DN, Kirlin AC, Chitayat S, Munro K, Spencer HL, LeBrun DP, Smith SP. Functional redundancy between the transcriptional activation domains of E2A is mediated by binding to the KIX domain of CBP/ p300. Nucleic Acids Res. 2014; 42(11): 73707382.

2. Guo C, Hu Q, Yan C, Zhang J. Multivalent binding of the ETO corepressor to E proteins facilitates dual repression controls targeting chromatin and the basal transcription machinery. Mol Cell Biol. 2009; 29(10): 2644-2657.

3. Huang A, Zhao H, Quan Y, Jin R, Feng B, Zheng M. E2A predicts prognosis of colorectal cancer patients and regulates cancer cell growth by targeting miR-320a. PLoS One. 2014; 9(1): e85201.

4. Patel D, Chinaranagari S, Chaudhary J. Basic helix loop helix (bHLH) transcription factor 3 (TCF3, E2A) is regulated by androgens in prostate cancer cells. Am J Cancer Res. 2015; 5(11): 3407-3421.

5. Bolós V, Peinado H, Pérez-Moreno MA, Fraga MF, Esteller M, Cano A. The transcription factor Slug represses E-cadherin expression and induces epithelial to mesenchymal transitions: a comparison with Snail and E47 repressors. J Cell Sci. 2003; 116(Pt 3): 499-511.

6. Peinado H, Olmeda D, Cano A. Snail, Zeb and bHLH factors in tumour progression: an alliance against the epithelial phenotype? Nat Rev Cancer. 2007; 7(6): 415-428.

7. Ramkissoon LA, Horowitz PM, Craig JM, Ramkissoon SH, Rich BE, Schumacher SE, McKenna A, Lawrence MS, Bergthold G, Brastianos PK, Tabak B, Ducar MD, Van Hummelen P, MacConaill LE, PouissantYoung $\mathrm{T}$, Cho YJ, Taha $\mathrm{H}$, Mahmoud $\mathrm{M}$, Bowers DC, Margraf L, Tabori U, Hawkins C, Packer RJ, Hill DA, Pomeroy SL, Eberhart CG, Dunn IF, Goumnerova L, Getz G, Chan JA, Santagata S, Hahn WC, Stiles CD, Ligon AH, Kieran MW, Beroukhim R, Ligon KL. Genomic analysis of diffuse pediatric low-grade gliomas identifies recurrent oncogenic truncating rearrangements in the transcription factor MYBL1. Proc Natl Acad Sci USA. 2013; 110(20): 8188-8193.

8. Dohi O, Yasui K, Gen Y, Takada H, Endo M, Tsuji K, Konishi C, Yamada N, Mitsuyoshi H,
Yagi N, Naito Y, Tanaka S, Arii S, Yoshikawa T. Epigenetic silencing of miR-335 and its host gene MEST in hepatocellular carcinoma. Int $J$ Oncol. 2013; 42(2): 411-418.

9. Li L, Zhang A, Cao X, Chen J, Xia Y, Zhao H, Shen A. General transcription factor IIb overexpression and a potential link to proliferation in human hepatocellular carcinoma. Pathol Oncol Res. 2013; 19(2): 195-203.

10. Hoedt E, Chaoui K, Huvent I, Mariller C, Monsarrat B, Burlet-Schiltz O, Pierce A. SILAC-based proteomic profiling of the human MDA-MB-231 metastatic breast cancer cell line in response to the two antitumoral lactoferrin isoforms: the secreted lactoferrin and the intracellular delta-lactoferrin. PLoS One. 2014; 9(8): e104563.

11. Hanahan D, Weinberg RA. Hallmarks of cancer: the next generation. Cell. 2011; 144(5): 646-674.

12. Lindsey S, Langhans SA. Crosstalk of Oncogenic Signaling Pathways during EpithelialMesenchymal Transition. Front Oncol. 2014; 4: 358.

13. Riesewijk AM, Hu L, Schulz U, Tariverdian G, Höglund P, Kere J, Ropers HH, Kalscheuer VM. Monoallelic expression of human PEG1/MEST is paralleled by parent-specific methylation in fetuses. Genomics. 1997; 42(2): 236-244.

14. Vidal AC, Henry NM, Murphy SK, Oneko O, Nye M, Bartlett JA, Overcash F, Huang Z, Wang F, Mlay P, Obure J, Smith J, Vasquez B, Swai B, Hernandez B, Hoyo C. PEG1/MEST and IGF2 DNA methylation in CIN and in cervical cancer. Clin Transl Oncol. 2014; 16(3): 266-272.

15. Pedersen IS, Dervan PA, Broderick D, Harrison M, Miller N, Delany E, O'Shea D, Costello P, McGoldrick A, Keating G, Tobin B, Gorey T, McCann A. Frequent loss of imprinting of PEG1/MEST in invasive breast cancer. Cancer Res. 1999; 59(21): 5449-5451.

16. Moon YS, Park SK, Kim HT, Lee TS, Kim JH, Choi YS. Imprinting and expression status of isoforms 1 and 2 of PEG1/MEST gene in uterine leiomyoma. Gynecol Obstet Invest. 2010; 70(2): 120-125.

17. Png KJ, Yoshida M, Zhang XH, Shu W, Lee H, Rimner A, Chan TA, Comen E, Andrade VP, Kim SW, King TA, Hudis CA, Norton L, Hicks J, Massagué J, Tavazoie SF. MicroRNA-335 inhibits tumor reinitiation and is silenced through genetic and epigenetic mechanisms in 
human breast cancer. Genes Dev. 2011; 25(3): 226-231.

18. Deng W, Roberts SG. TFIIB and the regulation of transcription by RNA polymerase II. Chromosoma. 2007; 116(5): 417-429.

19. Tan S, Aso T, Conaway RC, Conaway JW. Roles for both the RAP30 and RAP74 subunits of transcription factor IIF in transcription initiation and elongation by RNA polymerase II. $J$ Biol Chem. 1994; 269(41): 25684-25691.

20. Yoon JH, Lee JM, Namkoong SE, Bae SM, Kim YW, Han SJ, Cho YL, Nam GH, Kim CK, Seo JS, Ahn WS. cDNA Microarray Analysis of Gene Expression Profiles Associated with Cervical Cancer. Cancer Res Treat. 2003; 35(5): 451-459.

21. Ahn WS, Bae SM, Lee JM, Namkoong SE, Han SJ, Cho YL, Nam GH, Seo JS, Kim CK, Kim YW. Searching for pathogenic gene functions to cervical cancer. Gynecol Oncol. 2004; 93(1): 41-48.

22. Koumenis C. ER stress, hypoxia tolerance and tumor progression. Curr Mol Med. 2006; 6(1): 55-69.

23. Koumenis C, Wouters BG. "Translating" tumor hypoxia: unfolded protein response (UPR)dependent and UPR-independent pathways. Mol Cancer Res. 2006; 4(7): 423-436.

24. Vaupel P, Mayer A. Hypoxia in cancer: significance and impact on clinical outcome. Cancer Metastasis Rev. 2007; 26(2): 225-239.

25. Jäger R, Bertrand MJ, Gorman AM, Vandenabeele P, Samali A. The unfolded protein response at the crossroads of cellular life and death during endoplasmic reticulum stress. Biol Cell. 2012; 104(5): 259-270.

26. Bi M, Naczki C, Koritzinsky M, Fels D, Blais J, Hu N, Harding H, Novoa I, Varia M, Raleigh J, Scheuner D, Kaufman RJ, Bell J, Ron D, Wouters BG, Koumenis C. ER stress-regulated translation increases tolerance to extreme hypoxia and promotes tumor growth. EMBO J. 2005; 24(19): 3470-3481.

27. Romero-Ramirez L, Cao $\mathrm{H}$, Nelson $\mathrm{D}$, Hammond E, Lee AH, Yoshida H, Mori K, Glimcher LH, Denko NC, Giaccia AJ, Le QT, Koong AC. XBP1 is essential for survival under hypoxic conditions and is required for tumor growth. Cancer Res. 2004; 64(17): 5943-5947.

28. Drogat B, Auguste P, Nguyen DT, Bouchecareilh M, Pineau R, Nalbantoglu J, Kauf- man RJ, Chevet E, Bikfalvi A, Moenner M. IRE1 signaling is essential for ischemia-induced vascular endothelial growth factor-A expression and contributes to angiogenesis and tumor growth in vivo. Cancer Res. 2007; 67(14): 67006707.

29. Kaur B, Khwaja FW, Severson EA, Matheny SL, Brat DJ, Van Meir EG. Hypoxia and the hypoxiainducible-factor pathway in glioma growth and angiogenesis. Neuro Oncol. 2005; 7(2): 134-153.

30. Guo XB, Jing CQ, Li LP, Zhang L, Shi YL, Wang JS, Liu JL, Li CS. Down-regulation of miR-622 in gastric cancer promotes cellular invasion and tumor metastasis by targeting ING1 gene. World J Gastroenterol. 2011; 17(14): 1895-1902.

31. Minchenko OH, Kharkova AP, Minchenko DO, Karbovskyi LL. Effect of hypoxia on the expression of genes that encode some IGFBP and CCN proteins in U87 glioma cells depends on IRE1 signaling. Ukr Biochem J. 2015; 87(6): 52-63.

32. Minchenko OH, Tsymbal DO, Minchenko DO, Kovalevska OV, Karbovskyi LL, Bikfalvi A. Inhibition of ERN1 signaling enzyme affects hypoxic regulation of the expression of E2F8, EPAS1, HOXC6, ATF3, TBX3 and FOXF1 genes in U87 glioma cells. Ukr Biochem J. 2015; 87(2): 76-87.

33. Auf G, Jabouille A, Guérit S, Pineau R, Delugin M, Bouchecareilh M, Magnin N, Favereaux A, Maitre M, Gaiser $\mathrm{T}$, von Deimling A, Czabanka M, Vajkoczy P, Chevet E, Bikfalvi A, Moenner M. Inositol-requiring enzyme 1alpha is a key regulator of angiogenesis and invasion in malignant glioma. Proc Natl Acad Sci USA. 2010; 107(35): 15553-15558.

34. Auf G, Jabouille A, Delugin M, Guérit S, Pineau R, North S, Platonova N, Maitre M, Favereaux A, Vajkoczy P, Seno M, Bikfalvi A, Minchenko D, Minchenko O, Moenner M. High epiregulin expression in human U87 glioma cells relies on IRE1 $\alpha$ and promotes autocrine growth through EGF receptor. BMC Cancer. 2013; 13 : 597.

35. Minchenko OH, Kharkova AP, Bakalets TV, Kryvdiuk IV. Endoplasmic reticulum stress, its sensor and signaling systems and the role in the regulation of gene expressions in malignant tumor growth and hypoxia. Ukr Biokhim Zhurn. 2013; 85(5): 5-16. (In Ukrainian). 
36. Lenihan CR, Taylor CT. The impact of hypoxia on cell death pathways. Biochem Soc Trans. 2013; 41(2): 657-663.

37. Chesney J, Clark J, Klarer AC, ImbertFernandez Y, Lane AN, Telang S. Fructose-2,6bisphosphate synthesis by 6-phosphofructo-2kinase/fructose-2,6-bisphosphatase 4 (PFKFB4) is required for the glycolytic response to hypoxia and tumor growth. Oncotarget. 2014; 5(16): 6670-6686.

38. Minchenko DO, Danilovskyi SV, Kryvdiuk IV, Bakalets TV, Lypova NM, Karbovskyi LL, Minchenko OH. Inhibition of ERN1 modifies the hypoxic regulation of the expression of TP53- related genes in U87 glioma cells. Endoplasm Reticul Stress Dis. 2014; 1(1): 18-26.

39. Minchenko OH, Tsymbal DO, Minchenko DO, Moenner M, Kovalevska OV, Lypova NM. Inhibition of kinase and endoribonuclease activity of ERN1/IRE1 $\alpha$ affects expression of proliferationrelated genes in U87 glioma cells. Endoplasm Reticul Stress Dis. 2015; 2(1): 18-29.

40. Denko NC. Hypoxia, HIF1 and glucose metabolism in the solid tumour. Nat Rev Cancer. 2008; 8(9): 705-713.

Received 03.10.2016 